Historic, Archive Document

Do not assume content reflects current scientific knowledge, policies, or practices. 



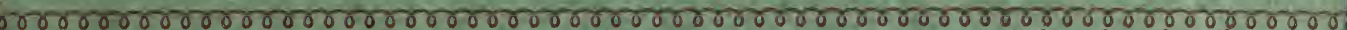

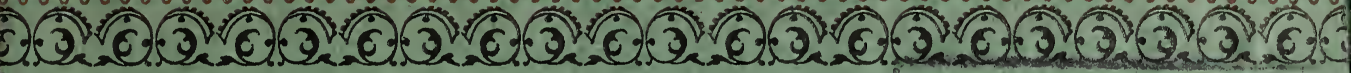

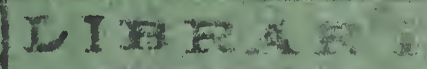
Ia movin Viss

画站turturu * FEB 101928 *

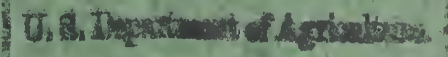
t.

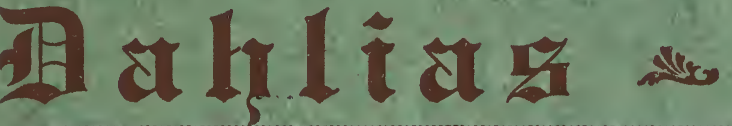
a
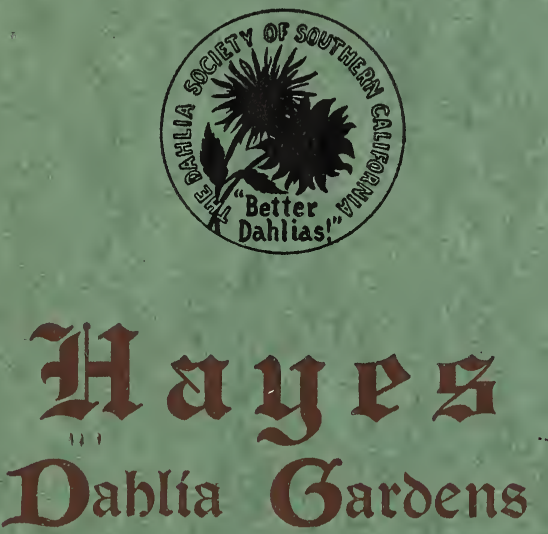

1146 Hegt Santa Zarbara Auenue Zlos Angeles, Calif.

$\overline{1920}$

Raymond C. Hayes

DAHLIA SPECIALIST

Phone UNibersity 9473 



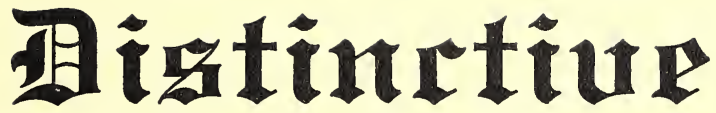

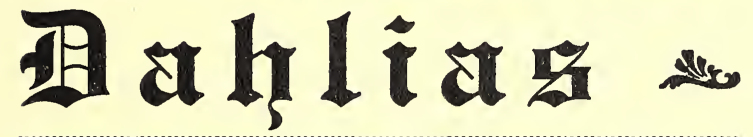

\section{Баaes Dablia Gardens}

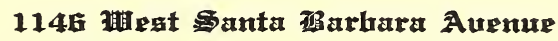

Zos Angeles, Calif.

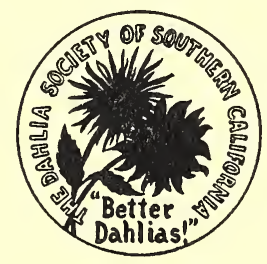

Raymond C. Hayes

DAHLIA SPECIALIST

Phone UNibersity 9473 


\section{To My Dahlia Friends -}

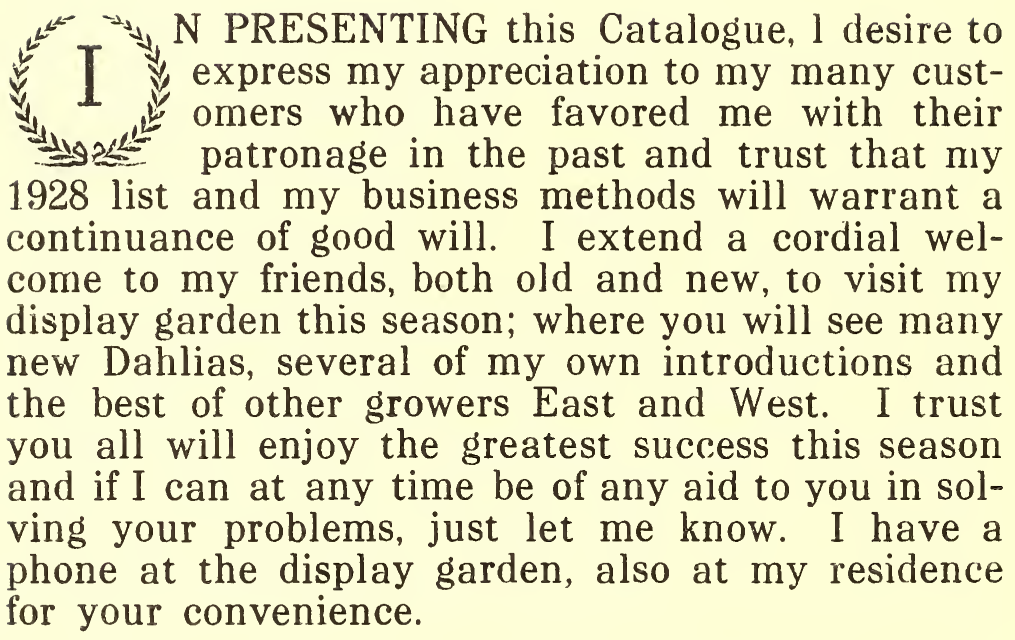

Yours for success,

$$
\text { Raymond C. Hayes }
$$

MEMBER $\left\{\begin{array}{l}\text { American Dahlia Society } \\ \text { Dahlia Society of San Francisco } \\ \text { Dahlia Society of Southern California }\end{array}\right.$ 


\section{The \\ Dahlia Society \\ of \\ Southern California}

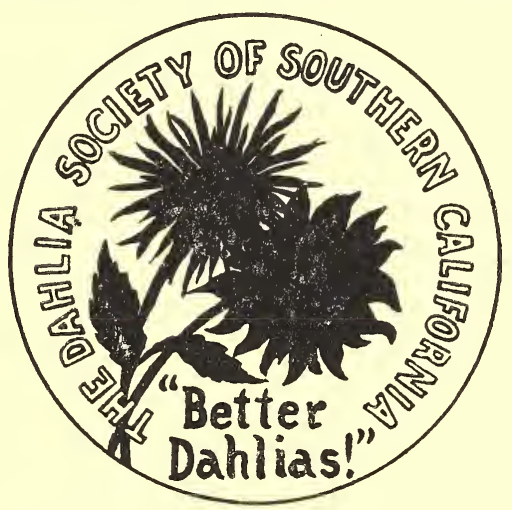

"It aims to unite ALL parties acceptable to one another, without regard to sex, occupation or profession, who feel an interest in Dahlia culture, especially for its own sake; to issue bulletins or other literature pertaining to the Dahlia and its culture; to arrange exhibits of the flower and to assist others in so doing; to work together in a spirit of helpfulness and cooperation; to the end that public taste may be stimulated, our homes made more beautiful, and that the glory of our State may be magnified.

- (Extract Constitution.)

\section{B}

As President of this Society, I extend to you a cordial invitation to become a member.

The yearly dues are $\$ 2.00$ which includes the Bulletin. It contains much of interest regarding the culture of the Dahlia.

The regular monthly meeting is held on the second Thursday of each month in the Committee Rooms of The Los Angeles Chamber of Commerce. 


\section{DAHLIA SEED}

Seed from Southern California ripen naturally. One of the most fascinating phases of Dahlia culture is growing from seed. To those of you who have not tasted this joy of seedling growing, I suggest you try this season; for the man or woman who has not watched a beautiful flower expand that has been brought into being by their own efforts, and has not been enthused and enraptured as Nature unfolded her handiwork, has missed-is missing-one of the joys of living.

The seed that I offer this season are the best I think it is possible to obtain. They are hand selected from the very best varieties that have proven good parents.

I can supply you with seed from the following varieties in separate packages at $\$ 5.00$ per hundred.

Al Koran. Ambassador. Aman Ra. Augusta R. Johnson. Bob Pleuss. California Beauty. Champagne. Clara R. Mills. Clara Spence. Cora Lee Dodson. Daddy Butler. Don Williams. Dr. Marshall A. Howe. Dr. Tevis. El Granada. Elinor Vanderveer. Elite Glory. Emma Marie. Eva Cole. Faith Garibaldi. Flaming Meteor. Geo. Walters. Gladys Sherwood. Islam Patrol. Jersey Beauty. Jersey's Beacon. J. W. Davies. Kittie Dunlap, Lillian Atchison. May DeVries. M. H. DeYoung. Millionaire. Mr. Crowley. Mrs. Carl Selbach. Mrs. Eleanor Martin. Mrs. F. A. C. Perrine. Mrs. Ida De Ver Warner. Mrs. John L. Gardner. Olive Reed. Paisley. Peggy. Radio. Rising Beauty. Rodman Wanamaker. Rookwood. Rosa Nell. Sagamore. Siskiyou. Susan G. Tevis. Stacy Trent. The Bandit. The Wizard of $\mathrm{Oz}$. Tommy Atkins. Trentonian. U. S. A. Wm. Kennedy.

Seed from above varieties mixed, $\$ 3.00$ per hundred.

Full Cultural directions with each order.

\section{SPECIAI, OFFER}

With every order of tubers amounting to \$15.00, I will enclose free, a package of 100 Dahlia Seed, value $\$ 3.00$.

With every order of tubers amounting to \$25.00, I will enclose. free, a package of 100 Dahlia Seed, (extra select) value $\$ 5.00$. 


\title{
New Introductions
}

\author{
篇
}

Rio Rita, Decorative-(My own introduction, 1928)

In this beauty I believe we have a combination of every desirable quality that tends to make a perfect Dahlia. First, the stem is perfect. Now that statement I realize covers a lot of ground, but Rio Rita has just that, a strong wiry stem that holds the full large blooms perfectly erect, and every bloom faces you. When cut with 36 inch stems you can, by holding the end in your hand, turn the flower over and over as you would a pan cake turner. The foilage is a rich green on plants 4 to 5 feet high, and the color Geranium Pink (Ridgeway) slightly suffused with white. A basket of these blooms was a prize winner in pink class, at the 1927 show of the Dahlia Society of Southern Cal., at the Biltmore Hotel, Los Angeles. As a commercial fiower is a top notcher.

\section{Tubers................ (net) $\$ 10.00$}

Marie Mondon, Decorative-(My own introduction, 1928)

This Dahlia will appeal to all who like a profuse bloomer. I have never seen a plant that would produce more large, uniform blooms than this one does. Each bloom held erect on a long, stiff stem. This new variety has a habit seldom found in a Dahlia that is producing two perfect blooms on the same stem, back to back opening at the same time. The coior is a blending of Mallow Pink and Wauvette (Ridgeway). Wonderful keeper.

Tubers. (net) $\$ 5.00$

Santa Monica, Hy. Cactus- (1928)

A brief history of this wonderful flower is most interesting, as it shows the possibilities that an amateur has with seedlings. The seed was planted by Mrs. Henry Bux- 
ton of Santa Monica, California, in 1924 and was entered in a contest in the fall of 1926, at the Dahlia Show at Santa Monica, California, competing for the award of the Dahlia to be chosen to bear the name of that city. However the local judges withheld the award that season. In 1927 this Dahlia was again entered at the same show as a contender and won over all. Mrs. Buxton did not wish to enter the commercial class by marketing her stock of this wonder so she decided to donate all proceeds to the Santa Monica Show, and they in turn have chosen me to distribute the stock to the public.

Santa Monica is a Hybrid Cactus with the quilled cactus qualities predominating, which makes the large blooms most desirable, from an artistic point. The color is a rosy lilac with center pure white. The plant is vigorous, of medium height. Very early bloomer and the very last to quit. Owing to its vigor, heavy disbudding is suggested. Blooms should not be cut until full open. As a keeper it has few rivals.

\section{Tubers............... (net) $\$ 15.00$}

\section{San Clemente, Decorative-New 1927 (Swisher)}

I am glad to be able to offer my friends a limited number of tubers of this introduction of $\mathrm{Mr}$. Lovell Swisher's. In 1926, San Clemente took first prize for the best established three year at the California Dahlia Show, Santa Monica, Calif., and the second prize the same year for the best established three year seedling at the Southern California Dahlia Society's show at Los Angeles. Also winner of inrst prize for best seedling class open to all and second prize for best Dahlia in show.

It is very difficult to describe the color of San Clemente as it is a distinct new break in coloring, being a rich brilliant rose color. It can be easily grown 11 to 12 inches, from beginning of season to the end. The size and color, however, are by no means the best features of this Dahlia as it has a perfect stem, fine foilage, and bears a profusion of bloom from the first of July, to the middle of Novernber. Last, and by no means least, it is an excellent keeper.

\section{Tubers............... (net) $\$ 7.50$ \\ No green plants.}

\section{Mollie Malone, Hybrid Cactus (Warren)}

\section{Color Effect:}

Yellow, Ridgeway; Amber Yellow, Self color. 8-inch blooms. Thrée foot stems. This bloom has the petalage of that unbeatable petaled Elsie Oliver and the color 
of Paul Michael. Petals incurve, and the top holds its circle. The livest bit of color in the whole Dahlia world for a self.

Tubers................(net) $\$ 10.00$

Kongo-Decorative

New 1928 introduction. This Red and Gold combination is most striking; the base is red, each petal is tipped with gold. Foliage and habit the best. As a seedling, Kongo has already won its share of prizes. This is a seedling introduced by Mrs. Hembree, of Santa Monica, California.

Tubers................ (net) $\$ 5.00$

\section{May De Vries (Dec.)}

My 1926 introduction. This dahlia has attracted attention wherever shown. The combination of pink and white, so perfectly blended, added to its enormous size of 10 and 11 inch blooms produced in profusion throughout this season, with long, stiff stems and perfect foliage make it most desirable. A bunch of these blooms was sent by air mail from Los Angeles to Chicago, arriving at their destination in good condition, proving its keeping qualities. This is the best dahlia I have introduced.

Tubers. (net) $\$ 7.50$

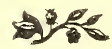




\section{General Price List}

\section{2}

Abalone (Dec.). Shell pink. This is one of the best of bloomers. The blooms close or cup at night, which gives them the appearance of a pond lily or lotus. Very early ...............................................\$.50

A. D. Lavoni (Show). Shell pink, standard cut flower.................... ..50

Alabaster. (Cac.). The finest white English Cactus. Large and incurved. An indispensible exhibition variety, beautiful for garden and a fine cut flower.

$\$ 1.00$

Alex. Waldie (Dec.). I regard this as one of the most beautiful decorative dahlias; the flowers are large, held above the foliage on fine stems, and the coloring is unsurpassed-a creamy ground overlaid with delicate salmon pink. This splendid dahlia was among the Prize Winners in the East, and has received high praise everywhere it has been shown

$\$ 1.00$

Al Koran (Dec.) Yellow, suffused with golden-rod and amber. The petals of this flower have the marcel wave which makes it very attractive. It won the first prize at the San Francisco and Oakland Shows in 1922 for the best established seedling.

$\$ 2.00$

Amber Glow (Cac). A bright yellow, deepening to pale orange at the center. The petals are long, narrow and straight. An exhibition and cut-flower variety.

1.00

Ambassador (Cac.). Color, soft yellow center, with salmon, amber and pink shadings. The flowers are the largest and set just right on perfect stems. A strong grower, free bloomer, fine keeper..... 2.00

Amun Ra (Dec.). The above Gold Medal Decorative Dahila is of gorgeous shades of copper and orange, shading to gold and amber, and deepening in the center to a rich dark reddish bronze................. 1.00

Augusta R. Johnson (Dec.). Yellow-buff shaded salmon; flowers very large and full centered; the color is very attractive, and extra good variety

1.00

A. R. Perry (Cac.) Old rose tipped gold. Large flower with incurved petals. Splendid for exhibition and very attactive in the garden $75 \mathrm{c}$

Arthur Twitchett (Cac.) Large blooms on good stems. Color a flesh white; very profuse bloomer. Good cut flower.

$\$ 1.00$

Astec Glory (Dec.). Picric yellow (lemon yellow), large flowers of most unusual formation held erect on strong stems, as an exhibition yellow decorative I have never seen its equal.

$\$ 10.00$

Ballet Girl (Cac.). Buff orange tipped white; red-striped white and solid buff; on the same bush. Splendid type and very large....... \$1.00

Earbara Redfern (Dec.). A delightful blend of old rose and old gold. Beautiful flowers of immense size and of great depth are bome on 
heavy stems. Begins blooming early and continues until the end of the season. Bushes are tall and vigorous growers and are pro-

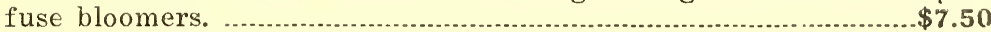

Eagle Rock Sunshine (Cac). A new California variety that is very beautiful. Bright golden yellow and stems are strong and upright. Blooms are very large and beautifully formed. A very fine Dahlia and a big prize winner.

$\$ 5.00$

Earl Williams (Dec.) Giant flowering dahlia. Color, a brilliant crimscn and white, well distributed. Free bloomer; one of the finest and most attractive dahlias ever introduced.

$\$ 1.50$

El Dorado (Dec.). An immense blossom of vivid gold, deepening in the center. This exceptionally fine Dahlia of great substance stands well out of the foliage of a low growing bush on strong, erect stem making it not only an exhibition variety, but an excellent cut flower. I have had fine reports of this Dahlia.

$\$ 3.00$

El Granada (Hyb. Cac.) Its color is a vivid orange, and the petals twist and interlace, showing at the tips a creamy yellow reverse. The beautiful flowers grow well out of the foliage on long, fine stems. It is an early bloomer. This is one of Bessie Boston's most sensational creations

$\$ 3.50$

Elinor Vanderveer (Dec.). An incomparable dahlia of exquisite beauty and great size. The large blooms of glowing, satiny rose pink are of great depth and substance, and are held far above a tall, sturdy bush on exceptionally long, stiff stems. There is no surplus leafage, and with ordinary disbudding every flower is perfect. This dahlia is said by many to be the best California dahlia ever put on the market.

$\$ 2.50$

Elite Glory (Dec.). A most sensational dahlia, with many prize winnings to its credit. The color is a brilliant rich red without any apparent purple or maroon shadings, and added to its other good qualities, it will keep remarkably long after cutting. Elite Glory may almost be regarded as a "break," and assuredly is not surpassed for spectacular effect for exhibition or garden.

$\$ 5.00$

Elizabeth Boston (Peony). Enormous blooms are of deep crimson, shading to old gold at the tips, and will hold its color the entire season. The center is surrounded with tiny, curly petais which make this introduction perfect of its type. Stems are exceedingly long and cane-like.

$\$ 2.00$

Faich Garibaldi (Dec.). This immense, deep rose decorative is a flower of great substance and of perfect formation. It does not require heavy disbudding for immense blooms. The stem is exceptionally strong, and carries the flower high above the foliage. The blossoms last indefinitely on the bush and nearly a week in the house. This dahlia has won many prizes in different parts of the country....\$3.00

Flaming Meteor (Dec.). The flower is large and of good depth, splendid form and unexcelled keeping qualities. The color is a flaming crange scarlet deepening to burnt orange at center where each petal shows an amber yellow base. The stems are long and cane-like. This new dahlia will be grown by everyone who loves rich colors.....\$5.00

Rob Pleuss (Hyb. Cac.). The color is a deep crimson maroon with the end of every petal on every flower for about half the length shading to a white. This dahlia was the cynosure of all cyes at 
the dahlia shows last year. A color not easily attained in a dahlia. All flowers on long stiff stems.

Bonnie Blue (Show). A true wisteria in color; good stems; wonderful keeper

B. P. O. E. (Show.) True Elks' purple; good stem; good keeper 50c

California Beauty (Cac.). The color is the nearest approach to a pure copper I have seen in a Dahlia. The flowers, of medium size, are produced in great profusion, much resembling the "Golden West" in shape and habit. As a cut flower this is certain to be in much demand. This flower was awarded first prize at Santa Monica, California, Dahlia Show, as the best commercial

$\$ .75$

Champagne (Dec.). This decorative seems blessed with all the dahlia qualities to make it a success. Color is delightful, warm autumn shades, varying from burnished copper to a dull golden champagne and chamois. Stem is heavy and holds the massive flower absolutely upright, and the bushes are plentiful producers of blooms. This decorative has always been a prize winner

$\$ 2.00$

Clara R. Mills (Dec.). This is one of my own introductions for 1926. A seedling from Rosa Nell. Color, deep American Beauty Rose. One of the truest of the decorative types. A dahlia unsurpassed for stem, keeping qualities and number of blooms. An early bloomer. Truly a wonderful dahlia

$\$ 3.50$

Cora Lee Dodson (Peony). This is one of the largest dahlias that I have ever grown. As a producer of large blooms and many of them it cannot be excelled. The color is immediateiy attractive, being a delicate yellow, with a primrose reverse. Foliage and stem are perfect. A 1926 introduction

Curtyne (Cac.). This is a true English cactus. A sport from Ballet Girl. Color, coral red. Petals decidedly incurved $\$ 1.50$

Daddy Butler (Hyb. Cac.) This is a large hybrid cactus of the truest form for exhibition, and a wonderful cut flower. A most unusual blending of colors. American Beauty shades of rosy carmine, and the reverse of the beautifully twisted and rolled petals is of a lighter tint, giving a variation of color. The stem is perfect, and the bush is always covered with large, perfect blooms, which last for days when cut

$\$ 1.50$

Del Norte (Dec.). The flower is a bi-color, amber, regularly tipped with flesh pink. Bushes bearing blossoms of two distinct shades, will at times produce flowers of only the strongest color. In this variety, this is most exceptional. Great big blooms, composed of narrow, curling recurved petals. The long stems are of lateral growth but hold the flower up stiffy. An abundance of flowers, on tall growing bushes, will glorify the garden all season and will be found most attractive in a vase.

$\$ 3.00$

Don Williams (Dec.). A seedling of Farl Williams, of a beautiful new shade of lavender, each petal being tipped snow white. F'ine stems, low growing plant. Will attract a great deal of attention in any garden

$\$ 2.50$

Dorothy Joyce (Peony). This dahlia should be used as a background in your garden, owing to the height of the plants, as it will easily grow eight feet. Stems three feet long. Color, pure old rose, blooms very large. A 1926 introduction $\$ 2.00$ 
Dr. Marshall A. Howe (Dec.). Large, light pink. Edge of petals a shade darker. Flowers nine inches. A good garden type.........\$1.50

Dr. Tevis (Dec.). Salmon rose, suffused with old gold, shading to apricot

Frances Seaman (Dec.). Silvery rose-pink, large, finely formed flowers held erect on fine stems; sure to become a favorite

F. W. Fellows (Cac.). Extra large and fine. The color is a light orange-scarlet or terra cotta; the best of its color .....................\$1.00

Gen. Joffre (Dec.). Silvery white. Each petal edged of lavender.

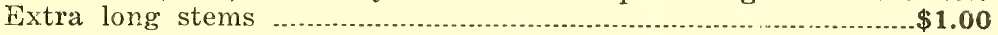

Ceo. Walters (Hyb. Cac.). Pink and salmon, tinged with gold at the center. This has always been one of the most popular dahlias since its introduction, and it used to be the saying, "If you grow only one dahlia, grow George Walters." It can be grown to enormous size, and has been awarded many prizes for the largest dahlia exhibited at numbers of shows. The color is very attractive, the shape almost perfect, and the stems fine

.$\$ .75$

Gee Whiz (Hyb. Cac.). A large, attractive Hybrid Cactus of soft buff, shading to salmon, with perfect long stems. A fine garden and exhibition variety

$\$ 1.00$

Gladys Sherwrood (Hyb. Cac.) An immense cream-white blossom, very deep and full to the center, having long, wide satiny-point ad petals that glisten in the sun. Flowers held erect on strong stiff stems $\$ 1.00$

Glorieux (Dec.). A flower of attractive beauty. Yellow deepening to bronze in the center, petals sometimes tipped white. Fine stems\$1.00

Golden West (Cac.). A rich golden yellow. The foliage is a very distinct light green; the plants are remarkably clean and healthy.

One of the greatest commercial dahlias ever introduced .........\$.50

Corgeous (Peony). Rightly named, yellow shading to bright scarlet. These gorgeous blossoms of tremendous size and great depth, stand erect on exceedingly long, stiff stems, and add striking beauty to the garden. Because of their unusual substance the blossoms are splendid exhibition and cut flowers. The plants grow very tall, and late blooms will be as large as early ones. This is one of the finest Peony dahlias I have ever grown and one of the most useful for exhibition

$\$ 2.00$

Grenadier (Dec.). This dahlia of huge size and depth, with slightly quilled petals, is purplish maroon on one side and silver on the other, but both colors show a very unique effect. The stems are long and strong and the bush always is covered with blooms ...............\$3.50

Hollowe'en (Dec.). Bufi-yellow, shaded orange-bronze. The flowers are held perfectly erect on the finest possible stems.................\$1.00

His Majesty (Dec.). The color is a bright scarlet, an extravagantly free bloomer and later flowers will retain their size, centre and substance. Does not require heavy disbudding to obtain size and stem. The dahlia is just naturally big

Harry Sheldon, Jr. An extra fine exhibition flower, white center with outer row of petals a beautiful shell pink. It can be grown very large and is a profuse bloomer with flowers held erect on strong stems

.$\$ 2.50$ 
Inkyo (Hyb. Cac.). This variety will appeal to those who like a dark one. The color is such a deep maroon, that in contrast with the lighter shades in the garden the effect is black, a vigorous, tal! grower early to late. Good keeper.

Insulinde (Dec.). Colossal flowers of a rich golden orange with orchid reverse. Form of flower everything that can be desired. Fine for cutting and exhibition, as it can be grown immense. One of the finest dahlias ever produced

$\$ 1.00$

Iriana (Dec.). The color of this is as near black as I have seen. A perfect decorative in form and a profuse bloomer. Good habit.

$\$ 5.00$

Islam Patrol (Hyb. Cac.). Very dark, velvety scarlet, tipped and flushed with gold. One of the outstanding California dahlias at all Eastern exhibitions held last season. Wonderful long stems, especially fine keeper for exhibition purposes. Winner of many prizes in California

$\$ 2.00$

Jean Chazot (Cac.). A French dahlia which it is a pleasure to grow and to recommend. A delightful autumn coloring of golden bronze suffused with nasturtium red. Flower is large and graceful and held erect on long strong stems. A most beautiful blossom for any use. Especially fine for cutting.

$\$ 1.00$

Jersey's Beauty (Dec.). Probably the most talked of dahlia among the Eastern introductions. It is still in a class by itself. A perfect bloom of Erosine pink, carried high above the foliage on a long wiry stem, a perfect true pink; wonderful keeper when cut, therefore good as an exhibition variety for commercial purposes. Awarded too many prizes and medals to enumerate $\$ 1.00$

Jersey's Beacon (Dec.). Chinese scarlet with a paler reverse, giving a two-toned efiect; very large fiower, vigorous grower, and has an excellent stem

$\$ 3.50$

J. W. Davies (Dec.). Color, the deepest shade of cerise at the center, graduating to a lighter tint, this blending of the two shade:s creating an entirely new effect. The large flower has depth as well as size; stem perfect, making it as good for cutting as for exhibition. Profuse bloomer

$\$ 2.00$

Kittie Dunlap (Dec.). Blooms freely all season, has excellent lieeping qualities, long firm stems, immense size, and great substance. It is of the delightful shade of the American Beauty rose. 'The petals are brosd, but have a slight tendency to roll. The long stems are practically without leaves $\$ 1.00$

Laddie (Dec.). Soft yellow-shaded orange; the brilliant orange tint in the depth of the flower gives it a glowing appearance that is fascinating. Large flowers are produced in profusion, and are held crect on strong stems; a most desirable cut flower .....................\$.50

La Favorita (Hyb. Cac.) Large hybrid cactus of new and distinct coloring, a most brilliant orange. Each bloom carried on a long stem. Always full to the centre. .............................................

La Mascotte (Dec.). Dahlia growers are always looking for some thing different in color or formation, and nothing gives more joy than to find a dahlia which is unusual. The unique coloring is a two-toned effect, as the petals are a silvery white with a deep violet reverse 
Liberty Bond (Dec.). A blending of buff, bronze, salmon shades very difficult to describe; the flowers are large, stems strong.

Lillian Atchison (Hyb. Cac.) This is a dahlia that will appeal to those desiring the very best. It has everything combined that go to make a perfect dahlia. The color is the purest shade of orchid on outer petals shading to a pure gold center. The effect of this combination is most pleasing. In general effect it suggests an immense sunburst. The growth and foliage are perfect, the stems easily average two feet. The best of my 1926 introductions. Stock limited $\$ \mathbf{5 . 0 0}$

Lolita Valasco (Cac.) Color, white; the petals are extremel. long and straight, the center excellent, and the size immense. 'The stem is very long and stiff, so the flower stands up and looks at you. American type cactus which always wins prizes.

$\$ 3.00$

Margaret Woodrow Wilson (Dec.). It is an exhibition type decorative of large size and great beauty. Color is opalescent pink. Face of petals creamy white; reverse, Phlox pink; the reflection from reverse of petals giving the whole fiower an opalescent effect. Petals are broad and well placed, terminating in points, making a thick flower. Strong upright stems, dark green foliage, medium height. A dahlia for all who want beauty, size and stem.

$\$ 5.00$

Marmion (Dec.). The color is pure golden yellow, with bronze suffusion on reverse of petals and a deeper bronzy tone on the center and outlining each petal. The stems are good and hold the immense blooms gracefully above the sturdy plant. Marmion is an excellent variety for the largest dahlia in show competition and has again won many prizes this year throughout the country and given much pleasure to all who grew it.

$\$ 7.50$

May DeVries (Dec.). This dahlia has attracted many visitors in my display garden. The combination of pink and white, so perfectly blended, added to its enormous size and profusion of blooms produced throughout the season, with its perfect foliage and long, stiff stems, is truly wonderful. A bunch of these blooms were sent by air mail from Los Angeles to Chicago, arriving at their destination in good condition, proving its keeping qualities

$\$ 7.50$

Millionaire (Dec.). This is undoubtedly one of the largest dahlias grown. Most delicate lavender, with a faint pink cast overshadowing it. The immense bloom of unusual depth stands erect on its stiff stem, and is an extremely valuable cut flower. This dahlia has won many prizes in the largest dahlia class

$\$ .50$

Mr. Crowley (Dec.). The color of this dahlia is a glowing shade of salmon pink; the base of the petals is yellow. In order to obtain the best results the crown buds should be removed, and also all but one of the buds on the branches, as they are borne on close terminal clusters. When this is done it can be cut with very good stems $\$ 1.00$

Mrs. C. Cooper... One of the largest cactus dahlias, on good stems, and free bloomex. Color, cream; outer petals lightly suffused salmon

Mrs. Carl Salbach (Dec.) Lavender pink in color, showing well up in the garden, as the immense blooms are held erect on especially long stiff stems. Being a perfect exhibition as well as cut flower makes this dahlia greatly in demand

$\$ 1.00$

Wrs. Ethel F. T. Smith (Kiyb. Cac.). Creamy white, shading to a limon tint in the center. It is a profuse bloomer on strong stems . ...\$.75 
Mrs. Eleanor Martin (Dec.). A California dahlia that does exceptionally well in the East; of a wonderfully rich coloring entirely different from anything else on the market. The color has been well described as "Mulberry." The petals are a peculiar rose shade with a reverse of violet. Stems long and stiff. Profuse bloomer $\$ 3.00$

Mrs. F. A. C. Perrine (Dec.) One of the most beautiful exhibition decorative dahlias in existence, of a lovely sharle of lilac with pale "Cattleya" reverse curiously twisted and curled petals, terminating in sharp points; a true staghorn type. Develops blooms from 8 to 10 inches in diameter on long, stiff stems. Stock limited $\$ \mathbf{\$ 4 . 0 0}$

Mrs. Ida DeVer Warner (Dec.). Large, periect flowers of charming color; a deep mauve-pink, on stout stems. A good grower and free bloomer. This is extra good. Many grow $1 \frac{1}{2}$ inches in diameter

$\$ 1.50$

Mrs. P. A. Vincent (Hyb. Cac.). The large flowers are of a glowing apricot buff, of perfect shape, and produced very freely on perfect stems; a remarkably good cut flower

$\$ 1.00$

Nichu (Hyb. Cac.). An extremely large light sulphur yellow Hybrid Cactus of perfect formation. The flowers have fine, long, stiff stems and remarkable keeping qualities, lasting for days when cut....\$3.00

Nobilis (Dec.). A beautiful combination of white and scarlet, with the white predominating. This variety is a sport from Farl Williams, and differs from it only in the amount of red in the flowers. Desirable where showy effects are wanted.

$\$ 1.50$

Norman (Cac.). A cactus with every good quality. The immense flower is composed of many exceedingly fine petals which give it great depth. The color is a beautiful maroon. Good for cutting, €xhibition or garden

$\$ 1.00$

Old Glory (Dec.). Rich maroon, occasionally tipped white. Good form $\$ 1.00$

Paisley (Dec.). This is a very unusual variegated, being a combination of dark maroon and light canary. It derived its name by suggesting in color scheme an old-fashioned Paisley shawl. An addition to any garden. 1926 introduction .............................\$3.00

Peggy (Hyb. Cac.). Rich yellow, shading to amber. A very compact flower of enormous size. A sturdy plant and abundant producer. Highly recommended. 1926 introduction

$\$ 3.50$

Perrella (1927 Novelty of Bessie Boston's). The color of this lovely dahlia is a bright rose pink, shading lighter on the outer petals which are long. The inner circle of petals show a trace of lavender. Perella is much pinker and without the lavender suffusion of Rookwood and the flower is much bigger but not as deep. The stem is long and stiff and grows out of the foliage and holds the flower up. Bushes grow to medium height, producing an abundance of perfect blooms from early to late season. The flowers are of excellent keeping qualities and are even more beautiful under artificial light when they are growing.

$\$ 7.50$

Pierrott (Cac.). A deep amber, boldly tipped white, making it a most striking combination which always attracts attention. The huge blossoms are perfect, being made up of many deeply-incurved petals, and have no superior for exhibition purposes .$\$ .75$ 
Polar Bear (Dec.). A large, pure white, with good stems and keeping qualities, putting it in a class with the best commercial whites of today. Has become very popular in this country, and also in England, where it received an Award of Merit at the Wisley Trials $\$ 1.00$

Polar Star (Hyb. Cac.). Large, white, good stems, good keeper...\$.50

Radio (Dec.). A 1924 introduction that has made a sensation. A large and attractive decorative of red and yellow. Stem excellent and fine for exhibition $\$ 5.00$

Ralph Ball (Dec.). Deep yellow, shading to gold at the base of the petals. The plants are of average height, with a heavy growth of foliage, and the stems are long and stout

$\$ 1.00$

Rheinischer Frohsinn (Cac.). The color is a deep rose, intermingled with white in such a manner as to give the whole a general tone of bright rose pink. This is one of the most satisfactory dahlias in my collection. The flowers are of good size and keep exceptionally well when cut. The stems are long and wiry

Rising Beauty (Hyb. Cac.). Color is a deep scarlet red, tipped and striped with yellow. It is one of the first to bloom, the bushes being constantly covered with large, striking flowers; the habit of the plant is most vigorous, the stems are long and rigid, and the flowers being well placed on the stems, stand high above the foliage. It is really one of the valuable additions to any collection.

$\$ 1.50$

Robert Treat (Dec.). This beautiful Eastern introduction has been one of the greatest prize winners wherever exhibited in that part of the country. This immense bloom of American Beauty rose color has a great substance and is held erect on long stems. Robert Treat is an exceptionally handsome variety and is always very popular in my garden

$\$ 2.50$

Rodinan Wanamaker (Hyb. Cac.). The buds are pale yellow, as is each petal as it first expands, but it quickly develops into a golden bronze salmon pink, and finally into a beautiful bright shade of Ochraceous salmon, with a reflex of spinel pink. The plant is a profuse bloomer, and they are a gorgeous sight with the many shades and tints of autumn so harmoniously blended.

$\$ 2.50$

Rose Fallon (Dec.). Splendid exhibition variety. Every flower of this beauty develops enormous size. Has won consistently in the Eastern shows for largest bloom. Color, rich old gold; held on long stiff stems

Tubers $\$ 5.00$

Rosemawr (Peony). Rose pink, very large. Tall grower; long stems $\$ 1.00$

Rosa Nell (Dec.). A deep, bright rose, a most unusual shade in dahlias, makes this variety one of the most striking and popular of the newer introductions; is considered by its originator as "the greatest of all decorative dahlias." The gigantic blooms are always full to the center, freely produced on long, stiff stems, and keep exceptionally well, both on the bush and when cut

$\$ 1.00$

Rookwood (Dec.). This dahlia is of an entirely new shade of rose, similar to the Mrs. Charles Russell rose, pure bright cerise rose, without the faintest touch of magenta, and it is as beautiful under artificial light as the Russell rose. Flowers are large, with a good depth, and are held aloft on splendid stems. The bushes grow low 
Santa Ana (Hyb. Cac.). One of the largest and best hybrid cactus in this coloring; beautiful salmon rose suffused with gold. The plant is of medium height and a free bloomer. The flowers are held well above the dark green foliage on good stems. The petals are long and wiry, giving the flower its striking form. Fine for exhibition purposes

Sagamore (Dec.). An exceptionally fine exhibition or cut flower, of a golden color, shaded toward the center with a warm salmon-rose or orange buff. Stems straight and stiff, and wonderful keeping qualities when cut, make this flower most desirable $\$ 2.50$

Shudows Lavender (Dec.). If you love delicate tones, there is no more beautiful flower than this lovely silvery lavender, slightly shading to white. This exquisitely beautiful flower with a long, stiff erect stem, is held high above an attractive lace-like foliage on a tall growing plant that is an ornament to any garden.

$\$ 2.00$

Silverhill Park (English Cac.). It is massive in size, beautifully incurved in form and with perfect center; color is a glistening white; the plants are strong and stems are good.

$\$ 1.00$

Siskiyou (Hyb. Cac.). This dahlia has always walked off with the prize for the largest fiower in the show. Flowers are held erect on very strong stems. The color is pink, tinged mauve. Siskiyou won the first prize for the largest flower in the 1926 Los Angeles Dahlia Show, the blooms shown being $12 \frac{1}{2}$ inches in diameter.

$\$ 2.50$

Stunner (Dec.). A large, light yellow of fine form. A strong, tall, sturdy grower of upright habit. Wonderful for cutting........\$1.00

Somerset (Dec.) Salmon to old rose. Very fine for all purposes. This dahlia won the Samuel Heller prize of $\$ 175.00$ in 1925 at Pasadena, California, for the best fifty blossoms originated in California

Susan G. Tevis (Dec.) An exceptional dahlia with a distinctive new color tone of a deep shade of lilac with a bluish sheen. A very graceful bloom of fine depth and great size held high above a vigorous plant. The stems are long and strong.

$\$ 2.50$

Suzanne (Hyb. Cac.) Collor, Massicot yellow, blending through straw yellow to citron yellow at center; backs of petals look as if acajor red had been slightly dusted on. Good stems and a constant producer of large flowers

$\$ 1.00$

Sunny South (Hyb. Cac.). The color is a bright clear yellow without any shading, the flowers are immense in size, most pleasing in form, very full and deep in the center.

$\$ 2.00$

The Wizard of $\mathrm{O}_{z}$ (Dec.). It is a very large flower of refined appearance regardless of its mammoth size. The color is a rare shade of glowing amber pink, or soft salmon pink shades.

$\$ 3.00$

Tillamook (Dec.). Canary yellow; magnificent in form and very large bloom, 9 inches in diameter; the habit is good. Height, 4 feet.

Tubers $\$ 3.00$

Tommy Atkins (Dec.). The name was given this dahlia because of its stunning coloring, which is like the British soldier's tunic, scarlet. The large, deop blossom is attractively formed and is not stiff and formal. Stem exceptionally good, and it blooms early and con- 
tinuously. It is one of the brightest dahlias grown. I took first prize at the Fotel Biltmore Show, Los Angeles, last year with Tommy Atkins as the best six reds exhibited.

Trentonian (Dec.). A giant decorative dahlia of a shade that appeals and captivates at one glance, and is really symbolic of Autumn. The color is that of an "Indian's skin," a wonderful blending of old gold, amber and coppery bronze, the whole forming a flower of marvelous brilliancy, with a central zone of reddish bronze. The petals are broad and well-placed, with the appearance of velvet and constitution of leather, making a flower of great lasting qualities. This flower is highly recommended, either for garden or exhibition, for its size, stem and grand color

$\$ 2.50$

T. A. Leonard (Dec.). This variety is the first to bloom, as well as the last. Continuously produces immense blooms of deep cerise on good stems $\$ 2.00$

Tryphinnie (Dec.). Bright shell pink, tinting lighter at tips. Stems good, plants tall $\$ 1.00$

U. S. A. (Peony). A very beautiful dahlia of vivid orange coloring, very large and full, good stem and free bloomer.

$\$ 1.00$

Virginia Harsh (Peony). A most unusual and pleasing shade of pink; the large flowers, similar in shape to "Geisha," are borne well above the foliage in great profusion.

$\$ 1.00$

Vivandiere (Peony). Cerise carmine, shading lighter at the tips of the petals. The flower has a peculiar velvety texture that makes it most desirable. An immense deep peony. Stems excellent and free bloomer

$\$ 2.00$

West Park (Hyb. Cac.). Dark, rich red, medium size bloom, good stem, good keeper

Wm. Kennedy (Hyb. Cac.) First prize at Biltmore Show, Los Angeles, 1926 , for best yellow over all. Color, pure lemon yellow; staghorn tip, perfect stem and foliage. Produces immense yellow blooms in profusion. Wonderful keeping qualities. Truly a sensational dahlia

$\$ 2.50$

Yazoo (Dec.). This dahlia stands in a class by itself. As a producer of large blooms I have never seen its equal. Bushes are of medium height, with flower's in every stage of development during the entire blooming season. The color will immediately attract attention, being a real Chinese red. The blooms will average 10 inches; has a wonderful stem and perfect foliage. This dahlia attracted many visitors at the Biltmore Show last year. A 1926 introduction....\$2.50

Zante (Hyb. Cac.). A fine new Hybrid Cactus with every good feature. A large perfect flower of gold, heavily suffused with pink with a deeper shading toward the center. The blooms are perfect the entire season and never show an open center. The stems are extra long and stiff, and hold the blooms proudly erect. Zante can be highly recommended for all purposes. 
Achievement. Dark maroon. White collar.

Ami Nonin. A beautiful flower of a charming shade of old rose.

White collar

Dante. Dark maroon. White collar .......................................... 50

Delicacy. Pink. Pink collar .................................................... .50

Dora Fisher. Beautiful pink. White collar................................ 50

Gil Blas. Rose, edged yellow. White collar. Very fine............. .50

Innocentia. White ......................................................................

Mme. Gygax. Carmen rose. Yellow collars.................................. .50

Silver Medal. Large beautiful crimson-maroon, with each petal distinctly outlined in white, with a wide collar in contrast........

Souv. Belle Accueil. Orange-red, with a yellow collar, is one of the largest, as well as one of the most beautiful.................... $\quad .50$

Snowflake. Pure white. White collar ........................................... .50

Virginia Lee. Small rich red. White collar .............................. .50

Wm. Welch. Yellow, with white collar. The best collarette..... .50

\section{POMPONS}

Anna Von Schwerin. True pink .............................................. $\$$

Amber Queen. Golden amber ...................................................... .35

Ariel. Large buff .................................................................... 35

Bacchus. Bright scarlet ........................................................... 35

Billie Fletcher. Smallest pompom, bright rose ........................... .50

Bronze Beauty. Large rich buff, good stems............................... . 35

Dearest. Bright rose, reverse silver. Large. Good stems........... 5

Dee Dee. Best small lavender .................................................... $\quad .50$

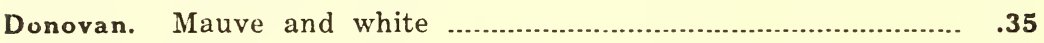

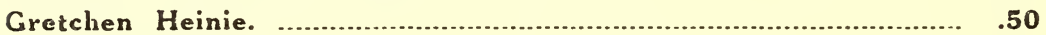

Doris. Cream. Fine form ..................................................... .35

Gannymede. Pink, edged yellow. Very fine .......................... 5

Joe Fette. Good white. Large................................................... .35

Klein Dolmatia. Orange-buff ................................................. $\quad .50$

Little David. Bronze ............................................. ....... 75

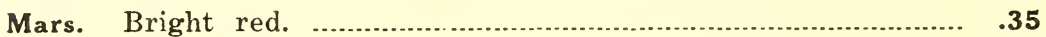

Mary Cliff. Purple. Good stems .............................................. .35

Neatness. Salmon pink .............................................................. .35

Nellie Bromhead. Mauve pink. Good form .........................................

Phoebe. Large orange ............................................................ .35

Sunny Daybreak. Yellow, edged red ..................................... 35

Tommy Kieth. Red and white .................................................... .35

Wee Gracie. White, lavender center ........................................... .35

\section{NOTE}

I have many varieties that I am not taking space to list. If there should be any number that you desire and do not find listed, I think I can supply you. 


\section{GREEN PLANTS}

During the last few years I have given considerable attention to green plants or cuttings, and I am entirely satisfied with the results. I find that green plants form good clumps of tubers that possess good keeping qualities. Green plants are much freer from disease than plants grown from tubers and invariably produce larger and better blooms. Green plants cost you about half the price of tubers and are far safer for the novice, as the plants that I offer are potted in 4-inch pots and are well established when delivered. Green plants will be sold in Los Angeles and vicinity only. I do not ship green plants.

Owing to my limited glasshouse space this season, I will have green plants from only a few selected varieties, so order early.

\section{PLEASE READ BEFORE ORDERING}

My tubers are all strong subdivisions taken from field-grown clumps, are guaranteed to be true to name, and when shipped to be in growing condition. Any that prove to be otherwise will be cheerfully replaced.

Order Early-Do not delay until planting time, as many varieties will be sold out. As orders are received, stock will be reserved, and sent at proper time, or sooner if requested.

Substitution-I do not substitute without permission.

Terms-Cash with order. Personal checks accepted.

Transportation-I prepay postage on all orders over two dollars.

\section{SPECIAL OFFER OF DAHLIAS}

For those not acquainted with the different varieties of dahlias. I will make up a collection of one dozen tubers of my own selection, all named varieties, for $\$ 5.00, \$ 10.00$ or $\$ 15.00$. In each case I will give good values and generous count.

\section{THE BOLLES DAHLIA BOOKLETS}

These little books cover well the entire culture of the Dahlia. I am offering the following volumes to my customers as a helpful guide.

Price, 50 cents each.

Cultivation of the Dahlia.

Propagation of the Dahlia.

Fertilizers and Large Blooms.

Enemies and Pests of Dahlias.

The Harvesting and Storage of Dahlias.

Dahlia Growing Commercially.

\section{STAKES}

I am in a position this season to supply my customers with genuine redwood stakes, 6 feet long by 1 by $1 \frac{1}{2}$ inches, pointed, per 100 , $\$ 10.00$. 
THE GOLDEN PRESS

Los Angeles, Calif. 


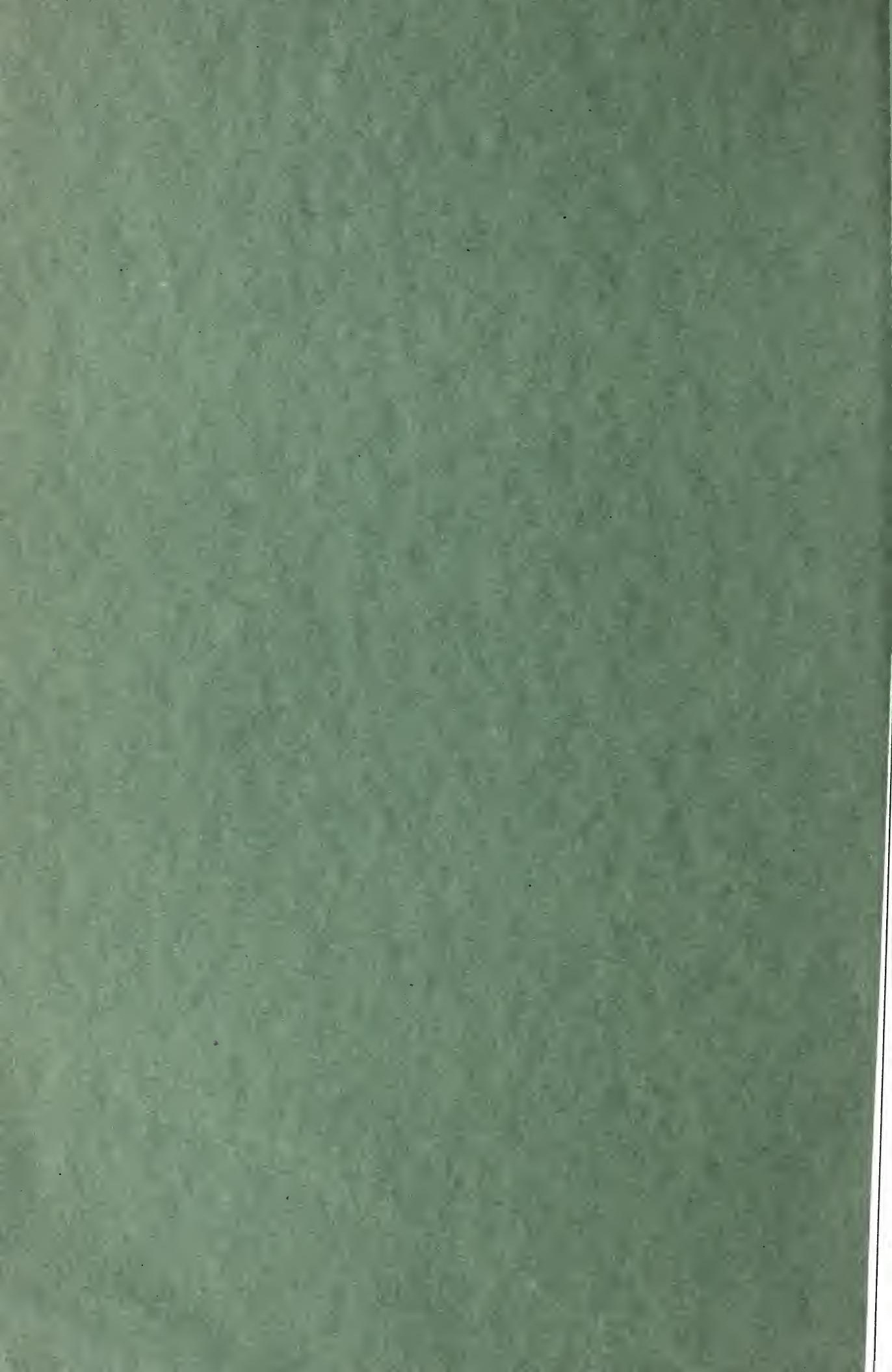

